\title{
Platinum containing sensor nanomaterials based on tin dioxide to detect methane in air
}

\author{
L.P.Oleksenko, G.V.Fedorenko, N.P.Maksymovych, I.P.Matushko
}

T.Shevchenko National University of Kyiv, 64/13 Volodymyrska Str., 01601 Kyiv, Ukraine

Received March 30, 2018

\begin{abstract}
Platinum-containing semiconductor materials on the base of nanosized $\mathrm{SnO}_{2}(14-$ $15 \mathrm{~nm}$ ) were obtained using a sol-gel technology. Catalytic properties of these materials in the methane oxidation reaction and sensitivities to methane of the sensors with gas sensitive layer based on the obtained nanomaterials were studied. It was shown that properties of the sensors are determined by quantity of platinum introduced to semiconductor material and maxima of the sensor responses to methane are reached when 0.72 and 1.76 wt. \% Pt are introduced. Created high sensitive adsorption-semiconductor sensors are stable and able to detect $\mathrm{CH}_{4}$ in air in a wide range of its concentration.

Keywords: nanomaterials, platinum, sensor, sensor response, catalytic activity, methane.

Платиносодержащие полупроводниковые материалы на основе наноразмерного $\mathrm{SnO}_{2}$ (14 - 15 нм) получены с использованием золь-гель технологии. Исследованы каталитические свойства этих материалов в реакции окисления метана и чувствительность к метану сенсоров, газочувствительный слой которых создан на основе полученных наноматериалов. Показано, что свойства сенсоров определяются количеством введенной платины в полупроводниковый материал, а максимальная чувствительность к метану достигается при введении 0,72 и 1,76 мас.\% Pt. Созданные высокочувствительные адсорбционно-полупроводниковые сенсоры являются стабильными и способны измерять $\mathrm{CH}_{4}$ в воздухе в широком диапазоне его концентраций.
\end{abstract}

Платиновмісні сенсорні матеріали на основі діоксиду олова для визначення метану у повітрі. Л.П.Олексенко, Г.В.Федоренко, Н.П.Максилович, І.П.Матушко.

Платиновмісні напівпровідникові матеріали на основі нанорозмірного $\mathrm{SnO}_{2}(14-$ 15 нм) отримано з використанням золь-гель технології. Досліджено каталітичні властивості даних матеріалів у реакції окиснення метану та чутливість до метану сенсорів, газочутливий шар яких створено на основі отриманих наноматеріалів. Показано, що властивості сенсорів визначаються кількістю введеної платини у напівпровідниковий матеріал, максимальна чутливість до метану досягається при введенні 0,72 та 1,76 мас.\% Pt. Створені високочутливі адсорбційно-напівпровідникові сенсори стабільні та здатні вимірювати $\mathrm{CH}_{4}$ у повітрі у широкому діапазоні його концентрацій.

\section{Introduction}

Nowadays development of new functional oxide nanosized materials is actual, in particular to create adsorption semiconductor gas sensors purposed to determine toxic and explosive gases in air.

Different oxide semiconductor materials, for example $\mathrm{SnO}_{2}, \mathrm{TiO}_{2}, \mathrm{ZnO}, \mathrm{ZrO}_{2}, \mathrm{WO}_{3}$
[1-5], can be used as materials for gas sensitive layers of the sensors. Tin dioxide is the most perspective material to create a gas sensitive layer of the sensor due to its chemical inertness and thermal stability [614]. It should be noted that usage of the nanosized tin dioxide, as a rule, leads to significant increasing a value of the sensor response $[15,16]$. In this case when the gas 
sensitive layer is heated a relatively greater quantity of oxygen can be chemisorbed on the sensor surface from the ambient air [17]. Due to localization of the conduction electrons of the semiconductor on the chemisorbed oxygen, the electrical resistance of the sensor in air is quite high $[15,18,19]$. In the presence of reducing gases in air the chemisorbed oxygen on the surface of the sensitive layer is used for their heterogeneous catalytic oxidation. A decrease in the quantity of the chemisorbed oxygen on the sensor surface results in the transfer of the previously localized electrons to the conduction band of the semiconductor that leads to a decrease in the electric resistance of the sensor [15, 17-19]. A degree of a change in the value of the resistance is greatly determined by the rate of the heterogeneous catalytic oxidation of the reducing gas by the oxygen chemisorbed on the surface of the sensor so that this rate affects the value of the sensor response. That is why catalytically active additives are introduced in the composition of the gas sensitive layer of the sensor to increase the sensor response.

Unlike other gases $[6-9,11-13]$, methane detection by the semiconductor sensors is rather difficult due to its chemical inertness [20-23]. Therefore, introduction of platinum, one of the most active catalysts for $\mathrm{CH}_{4}$ oxidation [21] to the sensitive layer of the sensors, should significantly increase the sensor response to methane. The aim of this work was to obtain and study Pt-containing nanomaterials based on $\mathrm{SnO}_{2}$ and to create on their basis a highly sensitive and stable adsorption semiconductor sensors capable to measure the presence of methane in air in a wide range of its concentrations.

\section{Experimental}

Initial $\mathrm{SnO}_{2}$ was obtained by a sol-gel route with $1,5 \mathrm{~g} \mathrm{SnCl}_{4} \cdot 5 \mathrm{H}_{2} \mathrm{O}$ and $15 \mathrm{ml}$ ethylene glycol as precursors. The reagents were mixed under stirring to dissolve $\mathrm{SnCl}_{4} \cdot 5 \mathrm{H}_{2} \mathrm{O}$. Then excess of ethylene glycol was evaporated in two steps: at $120^{\circ} \mathrm{C}$ (gel formation) and $150^{\circ} \mathrm{C}$ (xerogel formation). Formation of crystalline $\mathrm{SnO}_{2}$ was carried out in a high temperature furnace up to $600^{\circ} \mathrm{C}$ in air [24].

To create the sensors the initial powder of $\mathrm{SnO}_{2}$ was mixed with a binder (10\% carboxymethylcellulose solution in water) to form a paste. The paste was applied on the ceramic sensor plate between the measuring electrodes. Platinum was added to a gas sensitive layer by the wet impregnation technique. The ceramic plates with deposited paste were immersed in water solutions of hexachloroplatinic acid $\left(0.21-35 \cdot 10^{-2} \mathrm{~mol} / \mathrm{l}\right)$. After impregnation the plates were dried at $90^{\circ} \mathrm{C}$ and then calcinated up to $620^{\circ} \mathrm{C}$ in air [25]. Gas sensitive materials and catalysts were prepared by the same method as the sensors.

Morphology of the gas sensitive materials was studied by transmission electron microscopy (TEM) using the SELMI PEM-125K electron microscope (accelerating voltage was equal to $100 \mathrm{kV}$ ).

$\mathrm{X}$-ray diffraction (XRD) analysis of the obtained materials was conducted by using a diffractometer Bruker D8 Advance with CuK $\alpha$ radiation. Estimation of the XRD particle sizes of the nanomaterials was performed using the Scherrer equation [26]:

$$
D=\frac{k \lambda}{\beta \cdot \cos \theta},
$$

where $D$ is XRD particle size; $k$ is a constant close to unity (value 0.9 was taken for our calculation); $\lambda$ is the wavelength of CuK $\alpha$ radiation $(\lambda=1,5418 \AA) ; \beta$ is a true broadening of a diffraction peak $(\beta=\Delta-b$, where $\Delta$ is an experimental broadening and $b$ is an instrumental broadening); $\theta$ is a Bragg angle.

Platinum contents in the sensor materials were determined by X-ray fluorescence analysis using an energy dispersion X-ray spectrometer ElvaX EXS-01.

Catalytic activities of the gas sensitive materials were studied in a flow-type reactor using methane - air mixture $\left(930 \mathrm{ppm} \mathrm{CH}_{4}\right)$ with a flow rate $50 \mathrm{ml} / \mathrm{min}$. Outlet gas mixture analysis was performed by a chromatograph Shimadzu GC-14 with a flame ionization detector. The weight of the analyzed catalyst was $200 \mathrm{mg}$. A temperature of $10 \%$ conversion of methane in its oxidation reaction was chosen as a measure of the catalytic activities of the sensor materials.

For stabilization of the electric characteristics of the sensors they were periodically treated by the air-methane mixture $\left(930 \mathrm{ppm} \quad \mathrm{CH}_{4}\right)$ during 30 sec per each hour of sensor operation at $0.5 \mathrm{~W}$ within 3 days before the sensor response measurement. The heater power consump- 
tion was chosen as an analog of the sensor temperature. A ratio $R_{0} / R_{\mathrm{CH} 4}$ was taken as a measure of the sensor response, where $R_{0}$ is a value of an electric resistance of the sensor in air and $R_{\mathrm{CH} 4}$ is a value of an electric resistance in the presence of $930 \mathrm{ppm} \mathrm{CH}_{4}$. The used gas mixture was certified at the Ukrainian Center of Certification and Metrology. Methane-air mixtures with lower $\mathrm{CH}_{4}$ concentrations (less than $930 \mathrm{ppm}$ ) were obtained through dilution generators.

The values of the sensor signals in air and in the presence of methane were measured in a special electric stand [27]. The sensor was sequentially connected to a load resistor. The sensor electric resistance was calculated by the formula according to the Ohm's law for a series circuit connection:

$$
R_{s}=R \cdot \frac{\left(U_{p . s .}-U_{r}\right)}{U_{r}},
$$

where $U_{p . s .}$ is a value of voltage supplying by a power source at the sensor sensitive layer $(\mathrm{V}) ; U_{r}$ is a value of voltage at the load resistor (V); $R$ is a known value of the electric resistance of the load resistor $(\mathrm{Ohm}) ; R_{s}$ is a value of the sensor electric resistance $(\mathrm{Ohm})$ in air $\left(R_{0}\right)$ and in the analyzed gas mixture $\left(R_{\mathrm{CH} 4}\right)$.

Stabilities of the sensors during their long-term operation were estimated as deviations in the values of the electric resistances of the sensors in air $\left(\Delta R_{0}\right)$ and in the sensor responses to $930 \mathrm{ppm} \mathrm{CH}_{4}(\Delta \gamma)$ from initial values of these parameters in the 1 -st sensor operation day. The deviations were calculated by the following formulas:

$$
\begin{gathered}
\Delta R_{0}=\frac{R_{0_{1-\text { day }}}-R_{0_{i-\text { day }}}}{R_{0_{1-\text { day }}}} \cdot 100 \%, \\
\Delta \gamma=\frac{\gamma_{1-\text { day }}-\gamma_{i-\text { day }}}{\gamma_{1-\text { day }}} \cdot 100 \%,
\end{gathered}
$$

where $R_{0_{1-d a y}}$ is the electrical resistance in air of the sensor in the 1-st operation day; $R_{0_{i-d a y}}$ is the electrical resistance in air of the sensor in each of the following day of its operation ( $i$ - day); $\gamma_{1-d a y}$ is the response to $930 \mathrm{ppm} \mathrm{CH}_{4}$ in the 1-st operation day; $\gamma_{i-\text { day }}$ is the response to $930 \mathrm{ppm} \mathrm{CH}_{4}$ in each of the following day of its operation ( $i$-day).

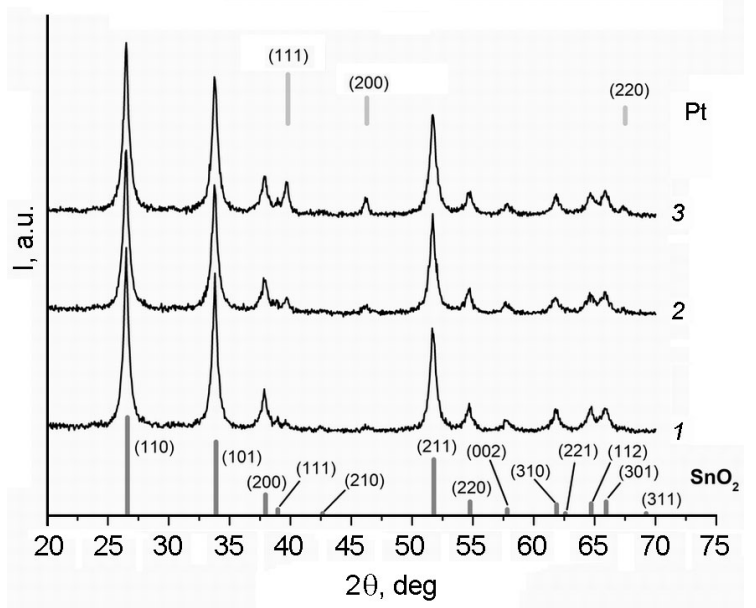

Fig. 1. Diffractograms of the samples: 1 1.76 wt. $\% \mathrm{Pt} / \mathrm{SnO}_{2} ; 2-2.93$ wt. $\% \mathrm{Pt} / \mathrm{SnO}_{2}$; $3-4.52$ wt. $\% \mathrm{Pt} / \mathrm{SnO}_{2}$; reflexes from the database for platinum and tin dioxide are indicated as $\mathrm{Pt}$ and $\mathrm{SnO}_{2}$, respectively.

\section{Results and discussion}

According to the TEM data sensor materials with different platinum contents $(0.03-4.52$ wt. $\%$ of $\mathrm{Pt})$ created on the base of the obtained nanosized $\mathrm{SnO}_{2}$ consist of discrete particles of predominantly spherical shape with an average size of 14 $-15 \mathrm{~nm}$. Study of the sensor materials with a high platinum content (1.76 wt. $\%$ $\mathrm{Pt} / \mathrm{SnO}_{2}, 2.93$ wt. $\% \mathrm{Pt} / \mathrm{SnO}_{2}, 4.52$ wt. $\%$ $\mathrm{Pt} / \mathrm{SnO}_{2}$ ) by XRD analysis has shown the presence of a cassiterite phase and metallic platinum (Fig. 1) and the reflexes corresponding to the metallic platinum are sufficiently broadened that indicates its nanoscale. An accurate calculation of XRD particle size of the metallic platinum by the Scherrer equation for the sensor material containing 1.76 wt. $\%$ of $\mathrm{Pt}$ was not possible because of low intensity of Pt reflections. Calculation of the XRD platinum particle size for the materials with the high Pt content showed that increasing the platinum in the samples led to increasing the particle size to $14 \mathrm{~nm}$ for the material containing 2.93 wt. \% of $\mathrm{Pt}$ and $18 \mathrm{~nm}$ for the nanomaterial 4.52 wt. $\% \mathrm{Pt} / \mathrm{SnO}_{2}$.

The values of the electrical resistances of Pt-containing sensors in air at their different heater power consumption are presented in Table 1. As can be seen, for the studied sensor materials with increasing the platinum content from 0.03 to $0.72-1.76$ wt. $\%$ (depending on the sensor heater power consumption) the 
Table 1. Electrical resistances of platinum-containing sensors in air

\begin{tabular}{||c|c|c|c|c|c||}
\hline \multirow{2}{*}{$P, \mathrm{~W}$} & \multicolumn{5}{|c|}{$R_{0}, \mathrm{kOm}$} \\
\cline { 2 - 6 } & 0.03 wt. \% of Pt & 0.72 wt. \% of Pt & 1.76 wt.\% of Pt & 2.93 wt.\% of Pt & 4.52 wt.\% of Pt \\
\hline 0.30 & 194 & 2221 & 4999 & 4443 & 3332 \\
0.35 & 165 & 2285 & 3635 & 2220 & 1784 \\
0.40 & 157 & 2104 & 1999 & 1289 & 1177 \\
0.45 & 150 & 1428 & 1142 & 740 & 678 \\
0.50 & 143 & 799 & 666 & 407 & 399 \\
\hline
\end{tabular}

values of $R_{0}$ sensors increaed too. This is probably due to the increase in the length of the interface between the platinum and tin dioxide particles $\left(\mathrm{Pt}-\mathrm{SnO}_{2}\right)$, which is a set of centers active for the chemisorption of oxygen on the gas sensitive layer surface [23, 27-32]. It was found that further increase in the platinum content in the gas sensitive layer (over 1.76 wt. \% of $\mathrm{Pt}$ ) leads to a decrease in the values of $R_{0}$ of the sensors at all of the investigated heaters power consumption (Table 1). This is apparently occurred due to aggregation of platinum on the surface of $\mathrm{SnO}_{2}$ leading to a decrease in the length of the $\mathrm{Pt}-\mathrm{SnO}_{2}$ interface.

As can be seen from the data of the Table 1, when the level sensor heaters power consumption is higher than $0.4 \mathrm{~W}$ the values of $R_{0}$ sensors containing 0.72 wt. $\%$ of $\mathrm{Pt}$ are relatively greater than those for the sensors containing 1.76 wt. $\%$ of Pt. Such values of the resistances for the sensors with a lower content of platinum can not be explained by the influence of the length of the Pt$\mathrm{SnO}_{2}$ interface. This is probably due to an another reason. As it is known [22, 33], binding energy of $\mathrm{Pt}-\mathrm{O}$ is higher for platinum clusters of smaller sizes. Therefore, at the high level of the sensor heater power consumption $(P \geq 0.4 \mathrm{~W})$, the quantity of oxygen chemisorbed on the surface of the gas sensitive layer with a lower content of platinum will be greater and it will lead to a higher values of the electrical resistances for these sensors. It should be noted that for the most of the studied sensors with different contents of platinum introduced, their electrical resistances in air decrease with increasing the sensor heater power consumption. Such changes can be caused by both temperature dependence of the own conductivity of the semiconductor and the desorption of the oxygen chemi-

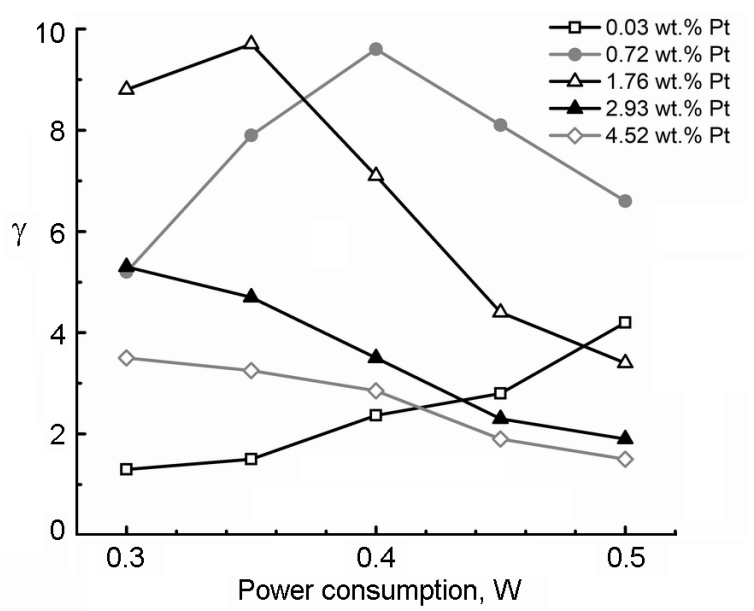

Fig. 2. Dependences of the responses of the platinum-containing sensors on heater power consumption.

sorbed on the gas-sensitive layer of the sensor as its temperature is raised.

It has been found that the sensors based on the nanosized tin dioxide without any additives have the very low value of the sensor response to methane $(\gamma \sim 1.5)$. The values of the responses for the sensors based on the nanomaterials with the low platinum content $(0.03$ wt. $\%$ of $\mathrm{Pt})$ at the sensor heater power consumption 0.3 $0.5 \mathrm{~W}$ are low, and the dependences of these sensor responses on the powers of the heaters have ascending characters (Fig. 2). It has been explained by the small length of the Pt-SnO ${ }_{2}$ interface as a result of low content of platinum introduced, the strong chemisorption of oxygen on the platinum clusters of the small size and, as a consequence, by the insignificant rate of the methane oxidation.

The values of the sensor responses to methane are higher for the sensors based on the nanomaterials 0.72 and 1.76 wt. $\%$ $\mathrm{Pt} / \mathrm{SnO}_{2}$ than for the sensors containing 0.03 wt. $\%$ of Pt. Besides the dependences of the responses on the heater power con- 

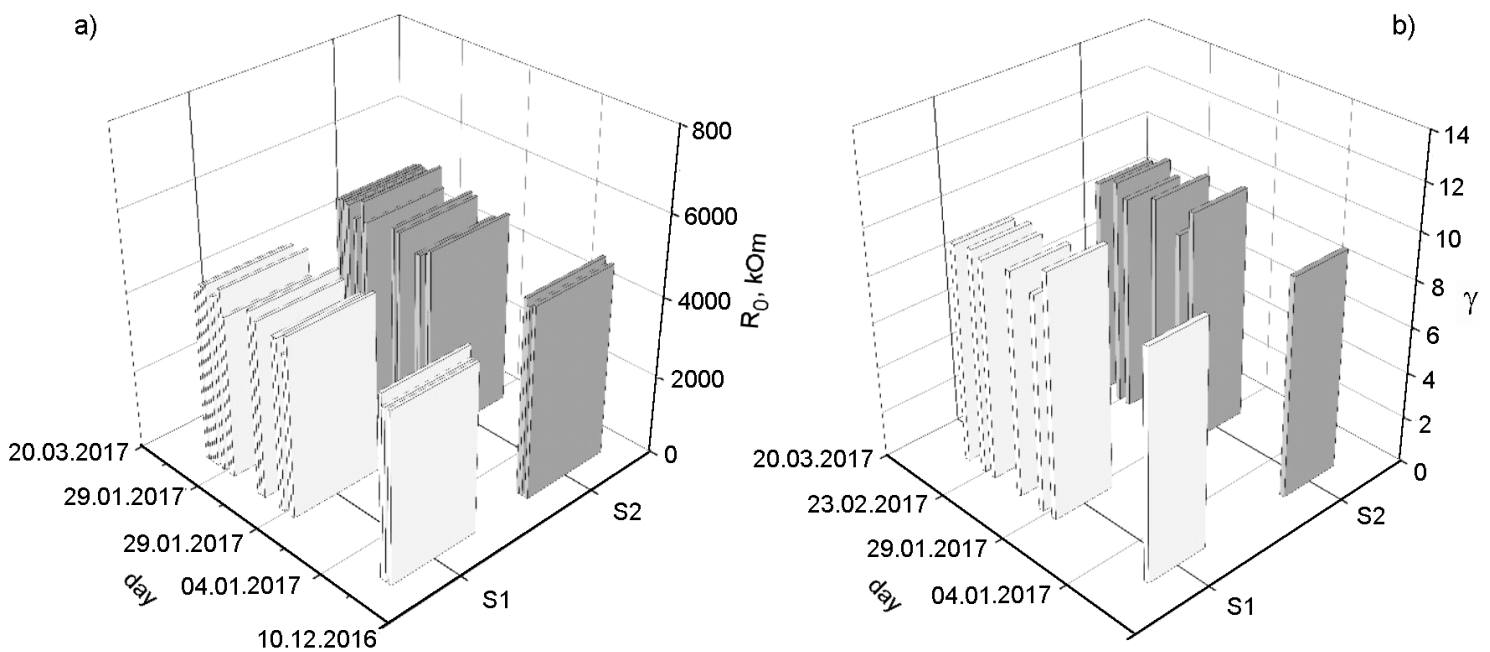

Fig. 3. Dependences of the values of the electrical resistances in air $\left(R_{0}\right)(\mathrm{a})$ and the responses $(\gamma)$ (b) of the sensors (S1 and S2) based on the nanomaterial $1.76 \mathrm{wt} \% \mathrm{Pt} / \mathrm{SnO}_{2}$ on time of their operation. Heater power consumption of the sensor was equal to $0.35 \mathrm{~W}$.

sumption are extreme with maximum at $0.4 \mathrm{~W}$ for the sensor with $0.72 \mathrm{wt} . \% \mathrm{Pt}(\gamma$ $=9.6$ ) and maximum at $0.35 \mathrm{~W}$ for the sensor with 1.76 wt. $\%$ of $\mathrm{Pt}(\gamma=9.7)$. Relatively higher values of the sensor responses can be explained by further increase in the length of the $\mathrm{Pt}-\mathrm{SnO}_{2}$ interface because of the higher content of platinum in the gas sensitive layer of the sensor, which leads to an increase in the quantity of the chemisorbed oxygen and thus to an increase in the rate of the methane oxidation reaction. At the same time blocking of the active centers of the interface $\mathrm{Pt}-\mathrm{SnO}_{2}$ by the products of the methane oxidation reaction can occur due to the increase in the reaction rate. Such blocking of the surface of the gas sensitive layer should reduce the response of the sensor to methane by excluding a part of the sensor surface which participates in the formation of its sensitivity. Naturally, the blocking should occur at the lower temperatures for the materials with a relatively greater quantity of the introduced platinum and, therefore, the maximum response of the sensors to methane is observed at a lower power of the sensor heater for the materials with $1.76 \%$ of $\mathrm{Pt}$ (Fig. 2). The occurrence of such blocking explains also decreasing the responses of the sensors at the further increase in their temperature.

Study of the catalytic activities of the synthesized Pt-containing materials has confirmed that the increase in the quan-
Table 2. Responses of platinum-containing sensors on methane concentration at different heater power consumption

\begin{tabular}{|c|c|c|c||}
\hline $\begin{array}{c}C\left(\mathrm{CH}_{4}\right), \\
\mathrm{ppm}\end{array}$ & $\begin{array}{c}0.4 \mathrm{~W} \\
0.72 \mathrm{wt} . \% \\
\text { of } \mathrm{Pt}\end{array}$ & $\begin{array}{c}0.35 \mathrm{~W} \\
1.76 \mathrm{wt} . \% \\
\text { of } \mathrm{Pt}\end{array}$ & $\begin{array}{c}0.3 \mathrm{~W} \\
1.76 \mathrm{wt} . \% \\
\text { of } \mathrm{Pt}\end{array}$ \\
\hline 195 & 4.6 & 4.5 & 4.1 \\
375 & 6.1 & 6.3 & 5.6 \\
560 & 7.2 & 7.5 & 6.6 \\
750 & 8.4 & 8.5 & 7.6 \\
930 & 9.5 & 9.6 & 8.7 \\
\hline \hline
\end{tabular}

tity of platinum in the samples actually contributes to the increase in their catalytic activities in the methane oxidation reaction. Thus, taking into account the temperatures of $10 \%$ methane conversion, the following row of the catalytic activities of the synthesized sensor materials was obtained: $\mathrm{SnO}_{2}$ without qadditives $\left(570^{\circ} \mathrm{C}\right)<0.03$ wt. $\%$ $\mathrm{Pt} / \mathrm{SnO}_{2} \quad\left(540^{\circ} \mathrm{C}\right)<0.72 \quad$ wt. $\% \quad \mathrm{Pt} / \mathrm{SnO}_{2}$ $\left(380^{\circ} \mathrm{C}\right)<1.76$ wt. $\% \quad \mathrm{Pt} / \mathrm{SnO}_{2} \quad\left(362^{\circ} \mathrm{C}\right)<$ 2.93 wt. $\% \quad \mathrm{Pt} / \mathrm{SnO}_{2} \quad\left(360^{\circ} \mathrm{C}\right)<4.52$ wt. $\%$ $\mathrm{Pt} / \mathrm{SnO}_{2}\left(352^{\circ} \mathrm{C}\right)$. Based on these data it can be expected that the blocking of the sensor surface by the reaction products will begin at the lower temperatures for the sensors with 1.76 wt.\% of Pt than for the sensors with 0.72 wt. $\%$ of $\mathrm{Pt}$ that corresponds to the observed behavior of the studied sensors.

For the sensors with a higher platinum content (2.93 and 4.52 wt. $\%$ of Pt), low 
sensor responses to methane are observed, and their dependences on the power of the sensor heaters have descending characters (Fig. 2). The reasons of such actions of the sensors are the small length of the $\mathrm{Pt}-\mathrm{SnO}_{2}$ interface due to the aggregation of platinum on the surface of the gas sensitive sensor layer, which occurs when $\mathrm{Pt}$ is introduced in high quantities, the low binding energy of the chemisorbed oxygen for the platinum clusters of the big sizes and the blocking of the part of the surface of the gas sensitive sensor layer because of the very high rate of methane oxidation reaction.

The study of the responses of the sensors at the power of their heaters that correspond to the highest sensitivities to methane has shown that the sensors can detect $\mathrm{CH}_{4}$ in air in a wide range of its concentrations (Table 2 ). In addition, the sensors based on the nanomaterial 1.76 wt. $\% \mathrm{Pt} / \mathrm{SnO}_{2}$ show the high values of the responses to the different methane concentrations at the lower power of the sensor heater $(0.3 \mathrm{~W})$ also, which makes the sensors to be promising for development of portable compact devices for detecting the presence methane in air.

The stabilities of the characteristics of the sensors based on the nanosized materials 1.76 wt. $\% \mathrm{Pt} / \mathrm{SnO}_{2}$, were studied during 4 months of their operation (sensors $\mathrm{S} 1$ and S2). The values of the electrical resistances in air of the sensors and their responses to $930 \mathrm{ppm} \mathrm{CH}_{4}$ during studied period are presented in Fig. 3. It was found that changes of these sensor parameters $\left(\Delta R_{0}, \Delta \gamma\right)$ did not exceed $\pm 10 \%$ during long-term operation of the sensors which indicates sufficient stabilities of the developed sensors.

\section{Conclusions}

Platinum containing semiconductor sensor nanomaterials on the base of nanosized $\mathrm{SnO}_{2}(14-15 \mathrm{~nm})$ were obtained using a sol-gel method. It was found that introduction of platinum leads to a significant increase of catalytic activities of these materials in the methane oxidation reaction that results in a change of their gas sensitive properties. It was shown that sensors based on the materials of the gas sensitive layer contained 0.72 and 1.76 wt.\% of $\mathrm{Pt}$ have a maximum of the sensor response to methane. Created on the basis of the obtained platinum containing nanomateri- als adsorption-semiconductor sensors are able to detect the presence of $\mathrm{CH}_{4}$ in air in its wide concentration range and they are stable during their long-term operation. This makes promising application the sensors in gas analysis devices designed to determine methane in air including detection of leakages of the natural gas.

\section{References}

1. S.Basu, A.Dutta, Mater.Chem.Phys., 47, 93 (1997).

2. I.Mulla, S.Pradhan, K.Vijayamohanan, Sens. Actuators, B, 57, 217 (1996).

3. V.Guidi, M.C.Carotta, M.Ferroni, J.Phys. Chem. B, 107, 120 (2003).

4. A.A.Tomchenko, V.V.Khatko, I.L.Emilianov, Sens.Actuators, B, 46, 8 (1996).

5. G.Kelp, T.Tatte, S.Pikker, Nanoscale, 8, 7056 (2016).

6. M.Batzill, U.Diebold, Prog.Surf.Sci., 79, 47 (2005).

7. G.De, A.Licciulli, C.Massaro et al., Sens.Actuators, $B$, 55, 134 (1999).

8. J.C.Kim, H.K.Jun, J-S.Huh et al., Sens.Actuators, $B$, 45, 271 (1997).

9. L.P.Oleksenko, N.P.Maksymovych, I.P.Matushko et al., Russ.J.Phys.Chem., A, 87, 265 (2013).

10. A.I.Buvaylo, L.P.Oleksenko, N.P.Maksymovych et al., Theor. Exp. Chem., 46, 153 (2010).

11. A.Cabot, J.Arbiol, J.R.Morante et al., Sens. Actuators, B, 70, 87 (2000).

12. L.P.Oleksenko, N.P.Maksymovych, L.V.Shuvar, I.P.Matusko, Theor. Exp.Chem., 49, 310 (2013).

13. F.Pourfayaz, Y.Mortazavi, A.Khodadadi, S.Ajami, Sens.Actuators, B, 130, 625 (2008).

14. L.P.Oleksenko, N.P.Maksymovych, E.V.Sokovykh, I.P.Matusko, Theor. Exp.Chem., 50, 115 (2014).

15. K.Geckeler, E.Rosenberg, Functional Nanomaterials, Amer. Sci. Publ., Valencia (2006).

16. N.Yamazoe, K.Shimanoe, Sens.Actuators, B, 138, 100 (2009).

17. A.V.Marikutsa, M.N.Rumyantseva, A.M.Gaskov, A.M.Samoylov, Inorg.Mater., $\quad \mathbf{5 1}, \quad 1329$ (2015).

18. C.Wang, L.Yin, L.Zhanget et al., Sensors, 10, 2088 (2010).

19. D.Kohl, Sens. Actuators, B, 18, 71 (1989).

20. T.Takeguchi, O.Takeoh, S.Aoyama et al., Appl. Catal., A, 252, 205 (2003).

21. R.Burch, M.J.Hayes, J.Mol.Catal.A:Chem., 100, 13 (1995).

22. A.Yu.Stakheev, A.M.Batkin, N.S.Teleguina et al., Top. Catal., 56, 306 (2013).

23. K.Persson, A.Ersson, K.Jansson et al., $J$. Catal., 231, 139 (2005). 
24. E.V.Sokovykh, L.P.Oleksenko, N.P.Maksymovych, I.P.Matushko, J.Therm.Anal.Calorim., 121, 1159 (2015).

25. L.P.Oleksenko, G.V.Fedorenko, N.P.Maksymovych, V.P.Ruchko, Ukr. Khim. Zh., 83, 30 (2017).

26. C.Hammond: The Basics of Crystallography and Diffraction, Oxford University Press, Oxford (2009).

27. G.V.Fedorenko, L.P.Oleksenko, N.P.Maksymovych, I.P.Matushko, Russ. J.Phys.Chem., $A, 12,2259$ (2015).
28. I.X.Green, W.Tang, M.Neurock, J.T.Yates, Science, 333, 736 (2011).

29. T.F.Jaramillo, K.P.Jorgensen, J.Bonde et al., Science, 317, 100 (2007).

30. W.P.Kang, C.K.Kim, J.Appl.Phys., 75, 4237 (1994).

31. L.P.Oleksenko, N.P.Maksymovych, E.V.Sokovykh et al., Sens.Actuators, B, 196, 298 (2014).

32. L.P.Oleksenko, G.V.Fedorenko, N.P.Maksymovych, Theor. Exp.Chem., 53, 259 (2017).

33. T.Frelink, W.Visscher, J.A.R.Veen, J.Electroanal. Chem., 382, 65 (1995). 